\title{
Effects of Trichoderma and Foliar Fertilizer on the Vegetative Growth of Black Pepper (Piper nigrum L.) Seedlings
}

\author{
Netty Syam (D), Hidrawati, St. Sabahannur, and Akbar Nurdin \\ Agrotechnology Program, Faculty of Agriculture, Universitas Muslim Indonesia, Makassar, South Sulawesi 90231, Indonesia \\ Correspondence should be addressed to Netty Syam; netty.said@umi.ac.id
}

Received 3 March 2021; Revised 15 May 2021; Accepted 26 June 2021; Published 6 July 2021

Academic Editor: David Clay

Copyright (C) 2021 Netty Syam et al. This is an open access article distributed under the Creative Commons Attribution License, which permits unrestricted use, distribution, and reproduction in any medium, provided the original work is properly cited.

Black pepper is a high nutrient-demanding crop; however, high application rates of the chemical fertilizer may give a negative impact on the environment and human health. Coapplication of the chemical fertilizer with biological fertilizers or biological agents is very important to support growth and high yield. This field experiment was carried out to study the effect of Trichoderma harzianum and foliar fertilization on the vegetative growth of black pepper. The study was conducted for 4 months. The research method was arranged in a factorial based on randomized block design (RBD). The first factor was the application of Trichoderma $(50 \mathrm{~g}, 75 \mathrm{~g}$, and $100 \mathrm{~g}$ per plant), and the second one was foliar fertilizers $(1.0 \%, 1.5 \%, 2.0 \%$, and without foliar fertilizer as the control). The treatments were repeated three times. The results showed that the application of both Trichoderma and foliar fertilizer affected the rate of shoot growth, the number of leaves, and the emergence time on black pepper seedlings under the nursery conditions. The application of $50 \mathrm{~g} /$ plant of Trichoderma and $1.5 \%$ of the foliar fertilizer resulted in $26 \%$ longer shoot length and 54\% more leaves and accelerated the appearance of shoots 10 days earlier compared to without Trichoderma and the foliar fertilizer.

\section{Introduction}

Black pepper (Piper nigrum L.) is one of the most economically important crops in Indonesia. It has an increasing role in many diets and medicinal applications and also plays an important role in the rural and farming systems of the country. Black pepper can be applied in the manufacture of traditional and modern medicines, nutraceuticals, perfumes, and other products. Also, pepper is used in many different forms. Several value-added products that have been developed include pepper oil, oleoresin pepper, green pepper brine, and other products $[1,2]$. With the development of modern science and technologies, greater awareness, and demand among the public for the use of natural products $[3,4]$, especially in food and medicine, pepper has indeed secured a better position and has better prospect in the coming years [5].

These benefits trigger the high demand for pepper from both domestic and world markets. This encourages farmers in Indonesia to cultivate crops more intensively. According to the data, the pepper planting area in 2019 reached 189,662 ha with a production of 89,902 tons [6]. Despite the extensive development of plantations, the productivity of Indonesian pepper in 2019 reached only $798 \mathrm{~kg} / \mathrm{ha}$. The production is not optimal, and there is even a declining trend. One of the factors causing the low pepper production is the infection of several pathogens such as Phytophthora spp. that significantly reduce plant growth and production. Root rot disease caused by a soilborne plant parasitic fungus Phytophthora capsici is a serious constraint in black pepper cultivation in Indonesia [7]. Contaminated planting materials or infected black pepper seedlings are important means of disease distribution in the region. The disease has been found in several important pepper-producing areas of Indonesia. The attack on the leaves will cause patches that extend to the entire leaf surface, while attacks on the base of the stem and roots can cause the plant to die [7].

Conventional crop protection is largely based on the use of chemical pesticides to control plant diseases and pests $[8,9]$, a practice that can have negative effects on end users 
and agroecosystem, including inhibition of pollinators, useful predators/parasitoid, and beneficial microbial communities [10]. Current trends in pepper cultivation and the applications of broad-spectrum organophosphate pesticides and high chemical fertilizers can contribute to environmental degradation $[3,8,11,12]$, besides shortening the life of the vines [13]. Different strategies have been raised to improve the efficiency of fertilization in crops [11, 14-16].

Soil fertility and the application of mineral nutrients in the form of chemical or organic fertilizers have an inevitable role in the overall growth of a plant, its performance, productivity, and its tolerance to stresses such as diseases [17-19]. Efforts are made to increase soil fertility in supporting plant growth, namely, by utilizing Trichoderma spp. as a biological agent that helps degrade organic matter so that more nutrients are available for plant growth [20-22]. Trichoderma spp., which have been studied extensively, are among the most commonly used microorganisms as biological control agents and are currently marketed as the active ingredients of biopesticides, biofertilizers, growth enhancers, and natural resistance stimulants. Applications of biological agents such as Trichoderma spp. are a useful and sustainable approach in improving soil fertility systems [22].

Trichoderma harzianum, a filamentous fungus, is used as a successful biological control agent to control different soilborne plant pathogens such as Pythium spp. Rhizoctonia solani, Fusarium spp., and Sclerotium rolfsii. It was demonstrated that $T$. harzianum induced defense responses and systemic resistance in addition to the control of plant pathogens [23]. In addition, several Trichoderma species promoted the growth and development of seedlings of vegetable and nonvegetable crops [24]. Moreover, yields of cucumber, bell pepper, and strawberry were significantly increased with the application of Trichoderma spp. [25].

As global demand for organic agricultural products increases, there is a need to develop healthy and sustainable agricultural practices for the improvement of the environment and the people who live in it $[26,27]$. At present, the organic approach is highly preferred in increasing the growth and productivity of black pepper plants [5]. In addition, the application of chemical fertilizers to the leaves shows several benefits over the application of the soil, especially in poor soil conditions or adverse climates $[17,28,29]$. Many studies had proven that the application of the foliar fertilizer was able to enhance the growth of spice crops by supplying secondary nutrients and micronutrients (zinc, manganese, iron, copper, boron, and molybdenum) and supplementing N-P-K needs for short and/or critical growth stage periods [14]. The previous study indicated that the application of the liquid fertilizer was able to increase the vegetative growth of black pepper in the field, and furthermore, there was a significant interaction when applied with Trichoderma [30]. The development of a liquid or foliar fertilizer represents a suitable method for effective minerals' delivery to plant tissues $[29,31]$. Therefore, the present study was undertaken to determine the efficiency of Trichoderma on the growth of black pepper seedlings when used in combination with foliar fertilizers under nursery conditions.

\section{Materials and Methods}

The research was carried out at a screenhouse in the Field Laboratory of Agriculture, Faculty of Universitas Muslim Indonesia, Padang Lampe, Pangkep Regency, South Sulawesi $\left(04^{\circ} 44^{\prime} 0^{\prime \prime} \mathrm{S}-119^{\circ} 37^{\prime} 0^{\prime \prime} \mathrm{E}\right)$, from May to October 2019. This location has a daily temperature varying from $25^{\circ}$ to $30^{\circ} \mathrm{C}$, has rainfall $3174 \mathrm{~mm} /$ year, mainly occurring from October to May (Climatology Station in Maros, South Sulawesi, 2019), and is at an altitude of $15-20 \mathrm{~m}$ above sea level.

The research was designed in the randomized block design (RBD) factorial with two factors. The first factor was the application of Trichoderma consisting of 3 levels, i.e., $25 \mathrm{~g} / \mathrm{plant}, 50 \mathrm{~g} / \mathrm{plant}$, and $75 \mathrm{~g} / \mathrm{plant}$, and without Trichoderma as the control. Trichoderma used was a solid formulation of Trichoderma harzianum. The second factor was the use of foliar/liquid fertilizers with a concentration that was $1.0 \%, 1.5 \%$, and $2.0 \%$ and without foliar fertilization as the control. Foliar fertilizer (trademark: Lestari Green) was applied once in two weeks; the nutrients' content of the fertilizer is shown in Table 1. The highest number of leaves was recorded at 3.53 leaves in seedlings treated with $50 \mathrm{~g} /$ plant of Trichoderma which was statistically different from other doses of Trichoderma and control.

There were 16 treatment combinations and 3 replications. Each treatment consisted of 5 polybags (plants), and there were 240 plants used. Pepper vines were obtained from Natar 1 variety pepper plants which were \pm 36 months old. The cuttings consisted of 2 segments, and 2 leaves (Figure 1) were obtained from a healthy pepper vine, a 3-year-old Natar 1 variety, which was prepared as the parent tree through the Trichoderma application one year before [13].

The potting mixture consisted of soil : sand : compost (1: $1: 1 \mathrm{w} / \mathrm{w})$ and had the nutrient composition of $0.20 \% \mathrm{~N}$, $20.04 \mathrm{ppm} \mathrm{P}$ and $\mathrm{O}, 0.78 \mathrm{mg} / \mathrm{L} \mathrm{K}_{2} \mathrm{O}$, and pH 5.98 (Table 1). The compost (Gliricidia sepium leaves) was used as a potting mixture (not sterilized) mixed with Trichoderma as per the treatment doses and filled into polybags $(17 \mathrm{~cm} \times 25 \mathrm{~cm}$ size $)$ with $1.5 \mathrm{~kg} /$ polybag. The data collected were analyzed by the analysis of variance (ANOVA) and post hoc comparison (Tukey's HSD test) at the significance level set at $\leq 0.05$.

\section{Results and Discussion}

3.1. Effect of Trichoderma on the Growth of Pepper Seedlings. Trichoderma treatment application has a significant effect on the growth properties of pepper plants. Data regarding shoot appearance time, number of shoots, shoot length, number of leaves, leaf area, and root volume are presented in Figure 2. The result showed that Trichoderma had a significant effect on shoot length at $p \leq 0.01$ and the number of leaves at $p \leq 0.05$, but there was no significant effect on shoot emergence time, shoot number, leaf area, and root volume. The highest shoot length was recorded at $12.35 \mathrm{~cm}$ in seedlings treated with Trichoderma $50 \mathrm{~g} /$ plant which was statistically similar to Trichoderma $75 \mathrm{~g} /$ plant, i.e., $11.78 \mathrm{~cm}$. However, Trichoderma $50 \mathrm{~g} /$ plant was statistically different with Trichoderma $25 \mathrm{~g} /$ plant $(9.38 \mathrm{~cm})$ and control $(9.81 \mathrm{~cm})$. 
TABLE 1: Chemical characteristics of the potting mixture and nutrient content of the fertilizer.

\begin{tabular}{lccc}
\hline Potting mixture & Values & Nutrient content of the fertilizer & Values \\
\hline $\mathrm{pH}$ & 5.98 & $\mathrm{pH}$ & 6.57 \\
$\mathrm{C}$-organic (\%) & 0.77 & $\mathrm{C}$-organic (\%) & 5.17 \\
$\mathrm{~N}$-total (\%) & 0.20 & $\mathrm{~N}(\%)$ & 5.25 \\
$\mathrm{C} / \mathrm{N}$ ratio & 3.85 & $\mathrm{C} / \mathrm{N}$ ratio & 0.99 \\
$\mathrm{P}_{2} \mathrm{O}_{5}(\mathrm{ppm})$ & 20.04 & $\mathrm{P}_{2} \mathrm{O}_{5}(\%)$ & 2.12 \\
Exchangeable $\mathrm{K}^{+}(\mathrm{cmol}(+) / \mathrm{kg})$ & 0.3 & $\mathrm{~K}_{2} \mathrm{O}(\%)$ & 7.94 \\
& & $\mathrm{SO}_{4}(\%)$ & 3.67 \\
& & $\mathrm{Ca}(\%)$ & 2.25 \\
Cation exchangeable capacity & 13.06 & $\mathrm{Mg}(\%)$ & 0.20 \\
& & $\mathrm{Cl}(\%)$ & 1.68 \\
& & $\mathrm{Fe}(\%)$ & 0.10 \\
& $\mathrm{Na}(\%)$ & 0.27 \\
\end{tabular}

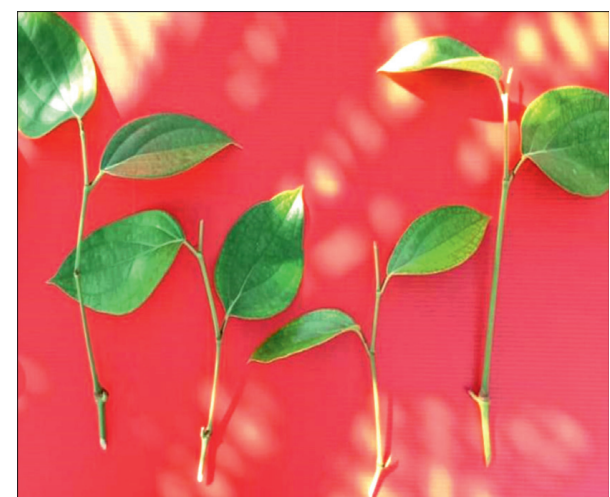

FIgURE 1: The cuttings used consisted of 2 segments and 2 leaves of Natar 1 variety.

Application of Trichoderma with doses more than $50 \mathrm{~g} / \mathrm{plant}$ tended to result in a smaller increase in shoot length. Length of the shoot of seedlings treated with $50 \mathrm{~g} /$ plant produced a longer shoot length of $31.73 \%$ compared with Trichoderma $25 \mathrm{~g} /$ plant and $25.91 \%$ compared with the control. Figure 3 shows that there was a significant relationship between the application of Trichoderma with the shoot length $\left(R^{2}=0.620\right.$, $r=0.787)$ with regression $(Y=-0.0354 x 2+1.0646 x+8.4$ 312). This is due to its ability to protect plants, enhance vegetative growth, and contain pathogen populations under numerous agricultural conditions, as well as to act as soil amendments/inoculants for the improvement of nutrient ability, decomposition, and biodegradation. Otherwise, the application of Trichoderma did not significantly affect the time of shoot emerging, but at a dose of $50 \mathrm{~g} /$ plant of Trichoderma, it was able to accelerate the emergence (35.47 days after planting) of pepper cuttings compared to other doses (Figure 2). There was a significant relationship between the application of Trichoderma with the emergence time of pepper shoots $\left(R^{2}=0.945, r=0.972\right)$ with regression $(Y=0.9771 x 2-4.7046 x+44.625)$ as shown in Figure 3.

The highest number of leaves was recorded in seedlings treated with $50 \mathrm{~g} /$ plant of Trichoderma which was statistically different from other doses of Trichoderma and control. The number of leaves produced from seedlings treated with $50 \mathrm{~g} /$ plant of Trichoderma was $34.60 \%$ more than the control,
$37.66 \%$ more than seedlings treated with $75 \mathrm{~g} /$ plant of Trichoderma, and even $63.08 \%$ more than seedlings treated with $25 \mathrm{~g} /$ plant of Trichoderma (Figure 2). Statistically, the application of Trichoderma did not have a significant effect on the emergence time of shoots, but at a dose of $50 \mathrm{~g} /$ plant of Trichoderma, it was able to accelerate the emergence (35.47 days after planting) of pepper cuttings compared to other doses (Figure 2). Increasing the Trichoderma dose higher than $50 \mathrm{~g} /$ plant resulted in a delay in the emergence of pepper cuttings. There was a significant relationship between giving of Trichoderma with the emergence time of pepper shoots $\left(R^{2}=0.945, r=0.972\right)$ with regression $(Y=0.9771$ $x 2-4.7046 x+44.625)$ as shown in Figure 3. The effect of Trichoderma on length of a shoot of pepper seedlings indicates a fairly close relationship, which can be seen in Figure 3.

The highest length of shoot and number of leaves were recorded in seedlings treated with $50 \mathrm{~g} /$ plant of Trichoderma, and this could be due to better provision of soil minerals and hormones to plant roots $[8,32,33]$. Several researchers have found similar evidence for a significantly higher increase in the number of leaves, tiller number, branches, flowers, fruits, and plant height by Trichoderma spp. which are available $[34,35]$. It has been shown that the rhizosphere isolates produce some metabolites that actively influence the growth of Trichoderma-colonized plants due to their action as plant growth regulators $[19,36]$. These compounds have optimum activity at low concentrations, while they have an inhibitory effect at high doses [37]. This condition may justify the observed inhibitory effect of the Trichoderma spp. in high doses.

\subsection{Effect of the Foliar Fertilizer on the Growth of Pepper} Seedlings. Application of chemical or organic fertilizers plays an important role in improving soil biochemical characteristics such as bulk density and increasing microbial activities, water absorption, and nutrient availability to the plant $[15,16,38]$. The analysis of variance of the data showed that the application of foliar fertilizer has a significant effect on emergence time of the shoot at $p \leq 0.01$, shoot length at $p \leq 0.05$, and the number of leaves at $p \leq 0.05$ compared to the control (without the fertilizer). However, fertilization 


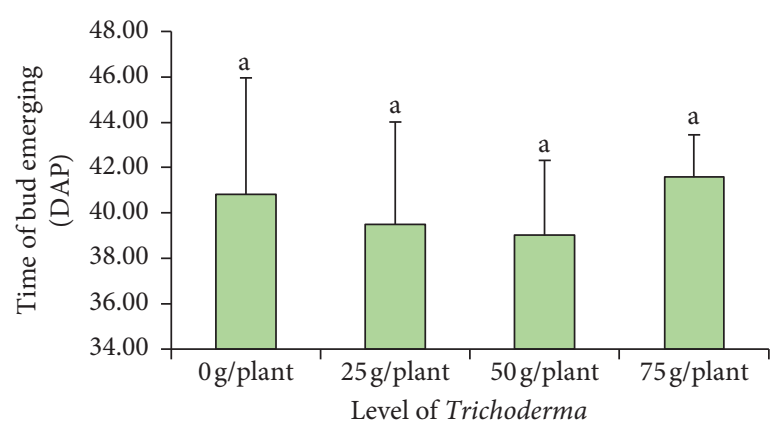

(a)

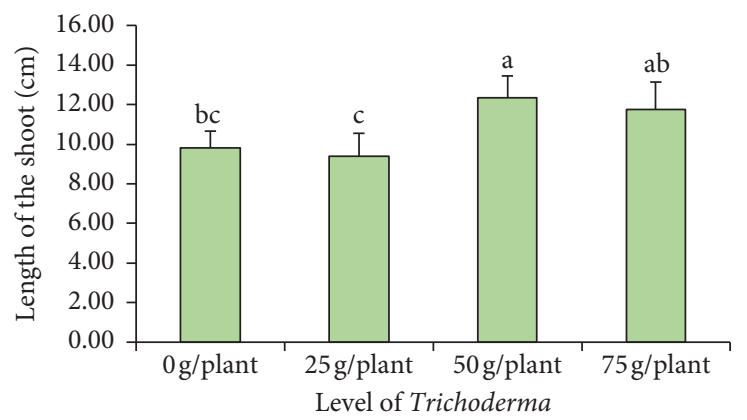

(c)

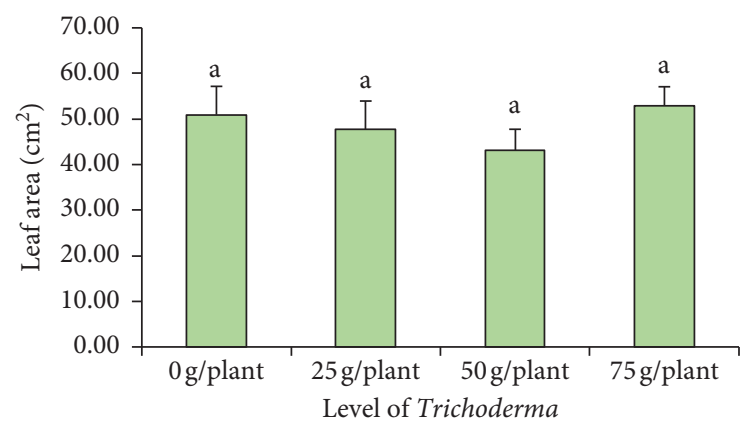

(e)

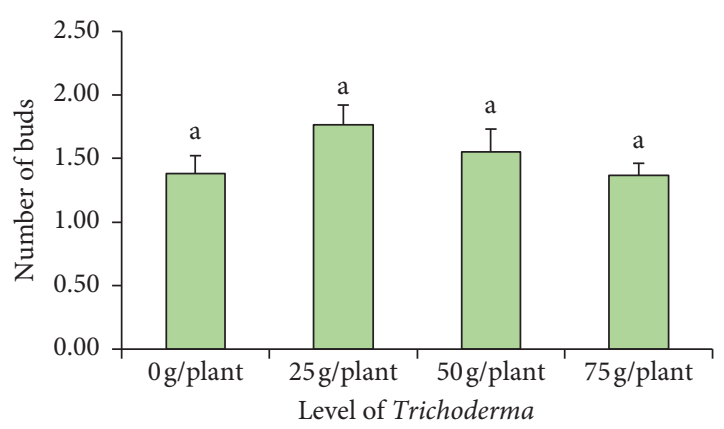

(b)

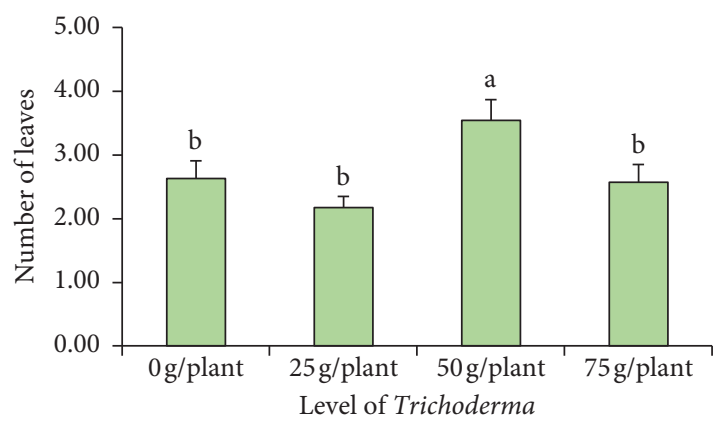

(d)

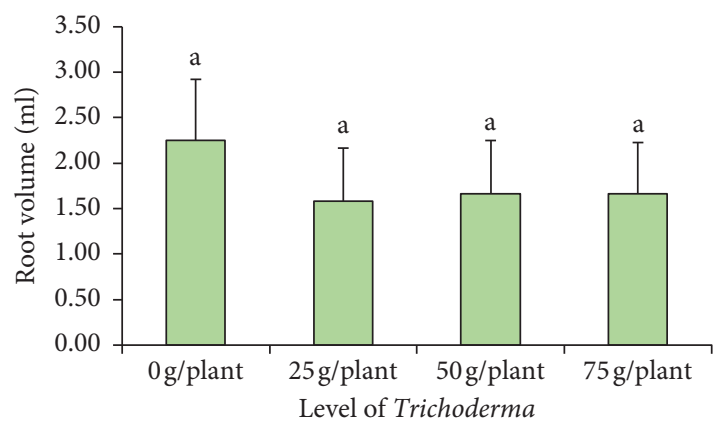

(f)

Figure 2: Effect of Trichoderma on (a) shoot emergence time, (b) shoot number, (c) shoot length, (d) the number of leaves, (e) leaf area, and (f) root volume of black pepper seedlings (after 8 weeks of planting). Different letters indicate significant differences among treatments as determined by Tukey's HSD test at the $p<0.05$ level. Vertical bars represent SE.

treatment had no significant effect on the number of shoots, leaf area, and root volume (Figure 4). Figure 4 shows that foliar fertilizer application at the concentration of $1.0 \%-$ $1.5 \%$ accelerated the emergence time of shoot, shoot length, and the number of leaves, which was significantly different from the control plant.

Foliar spray of the liquid fertilizer significantly increased the shoot length and the number of leaves compared to the control plant. The highest shoot length and leaf numbers were obtained from foliar fertilizer concentration 1.5\%. Application of the foliar fertilizer with a concentration higher than $1.5 \%$ resulted in the inhibition of the enhancement on shoot length and leaf numbers of pepper seedlings as shown in Figure 4. The results of the study show that the level of fertilizer application was highly significant to determine the emergence of shoots, the leaf numbers, and the shoot length of pepper seedlings using the regression models. It was found that the level of fertilizer application is well correlated to the emergence of shoots $\left(R^{2}=0.868\right.$, $r=0.931)$, the number of leaves $\left(R^{2}=0.991, r=0.995\right)$, and the shoot length $\left(R^{2}=0.994, r=0.997\right)$ as shown in Figure 5 .

These findings indicated that the application of foliar fertilizers could better supply minerals to plant leaves, resulting in better growth conditions [12,39-41]. This might probably be due to the better utilization of the nutrients supplied. The growth rates recorded from pepper seedlings from fertilization treatment indicated that fertilization through leaves on pepper cuttings plays an important role in the early growth of the plant. Ann reported [5] that the application of the organic fertilizer through leaves greatly affected the growth of pepper vines. Furthermore, Ann's [42] explanation for this condition is that, in the early stages of growth, especially when pepper cuttings are moved from the field, the root system is not fully developed, so absorption of 


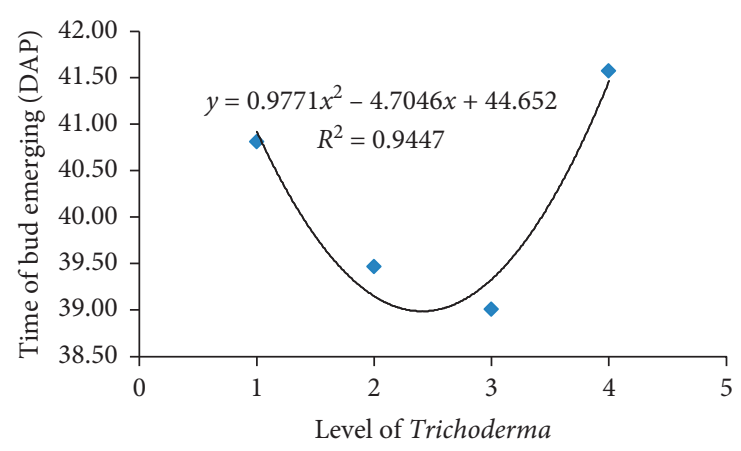

(a)

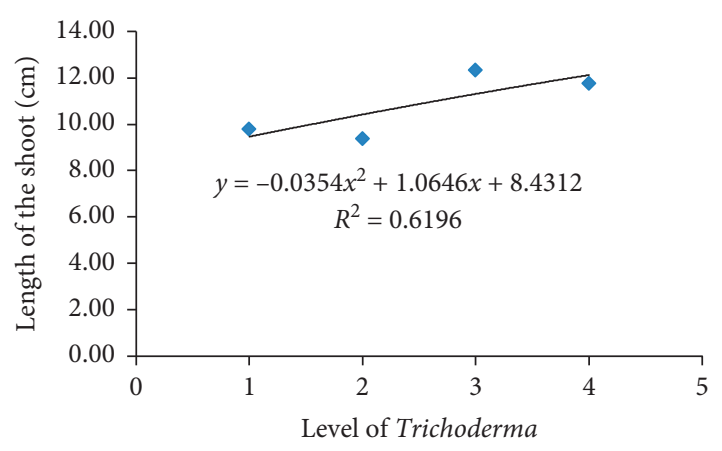

(b)

FIgURE 3: Regression analysis between the time of bud emerging (a) and length of the shoot (b) of pepper seedlings and doses of Trichoderma on pepper seedlings after 8 weeks of planting.

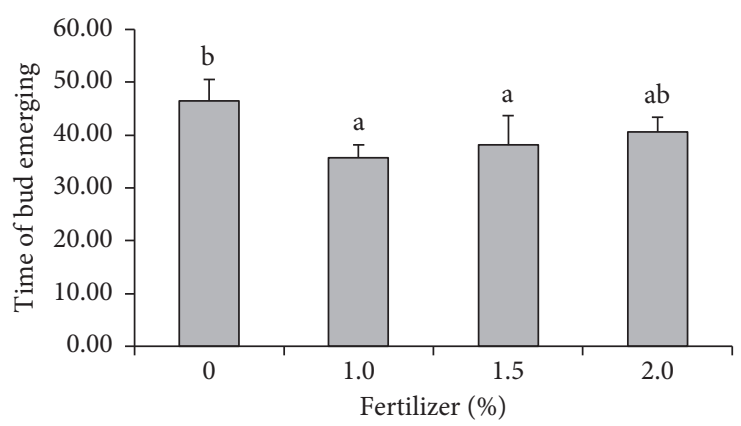

(a)

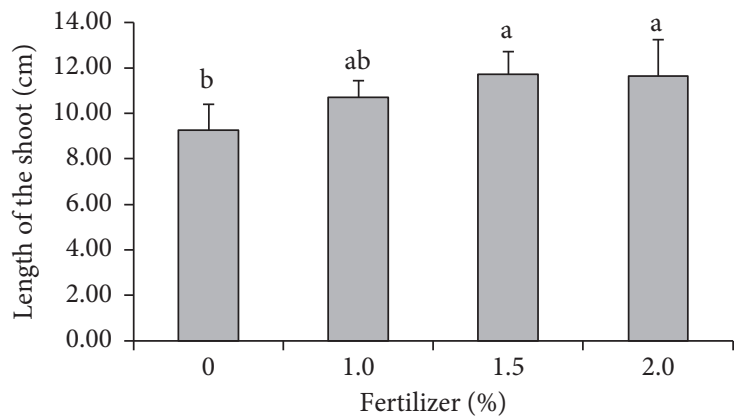

(c)

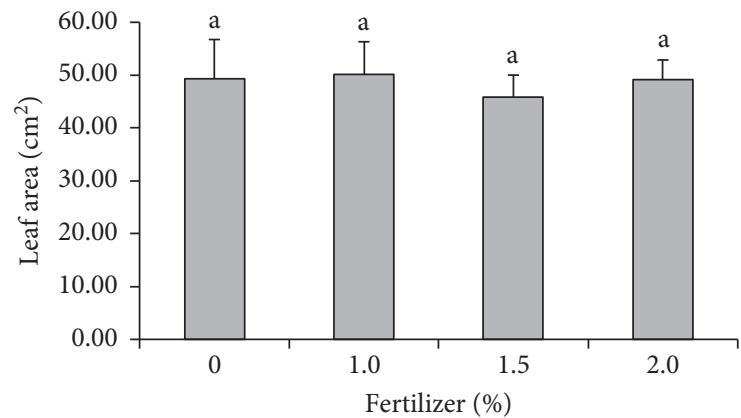

(e)

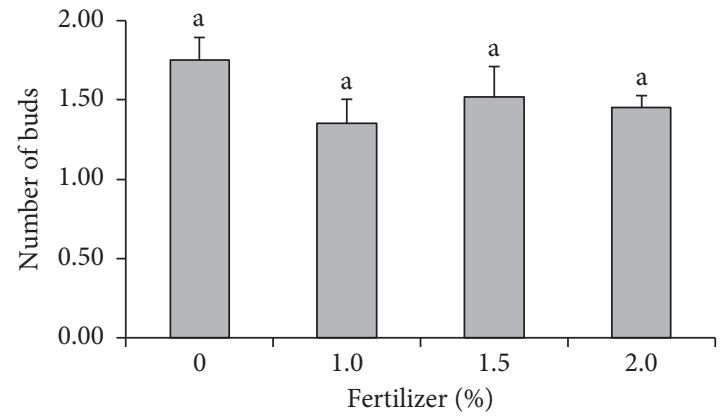

(b)

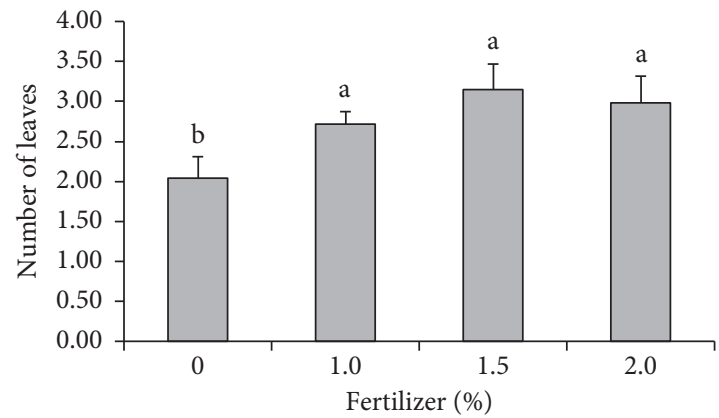

(d)

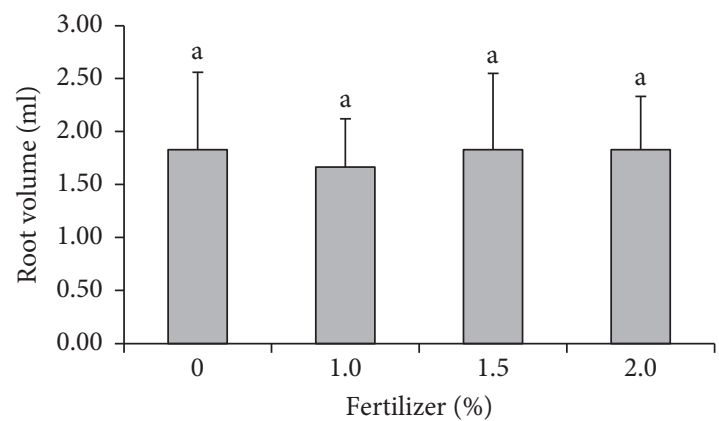

(f)

FIgURE 4: Effect of foliar fertilizer (FF) application on (a) emergence time of the shoot, (b) number of shoots, (c) shoot length, (d) the number of leaves, (e) leaf area, and (f) root volume of black pepper seedlings (after 8 weeks of planting). Different letters indicate significant differences among treatments as determined by Tukey's HSD test at the $p<0.05$ level. Vertical bars represent SE. 


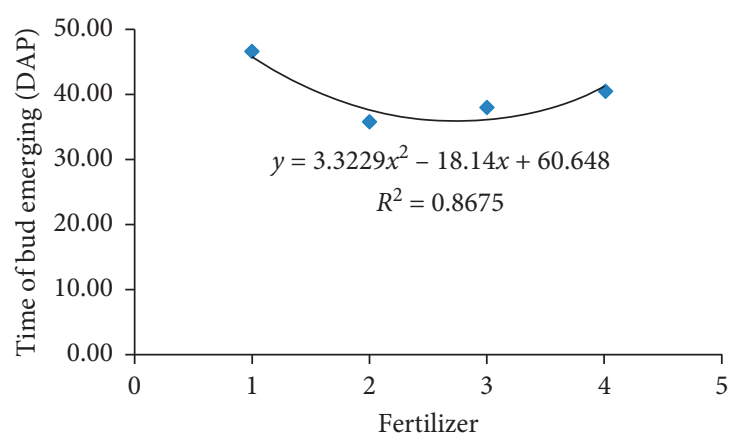

(a)

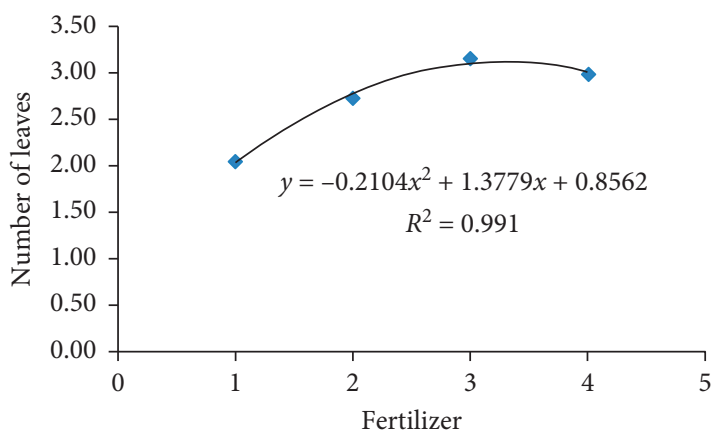

(b)

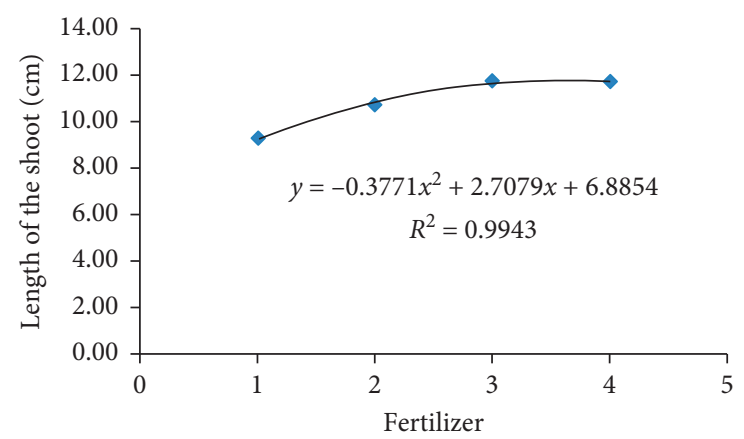

(c)

FiguRE 5: Regression analysis between foliar fertilizer application and time of bud emerging, number of leaves, and length of the shoot on pepper seedlings after 8 weeks of planting.

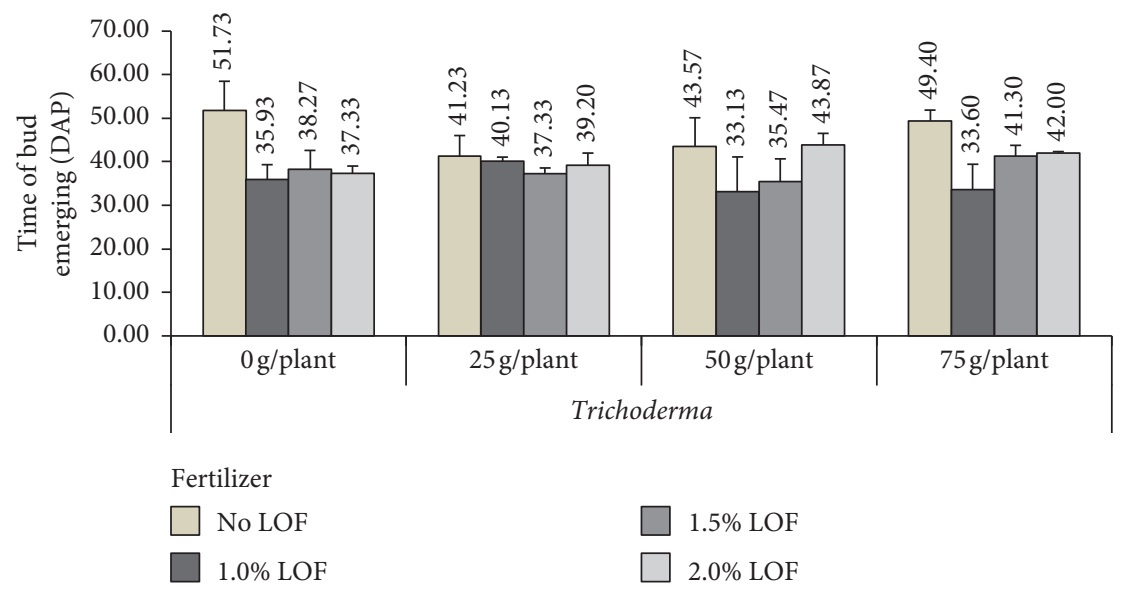

(a)

Figure 6: Continued. 

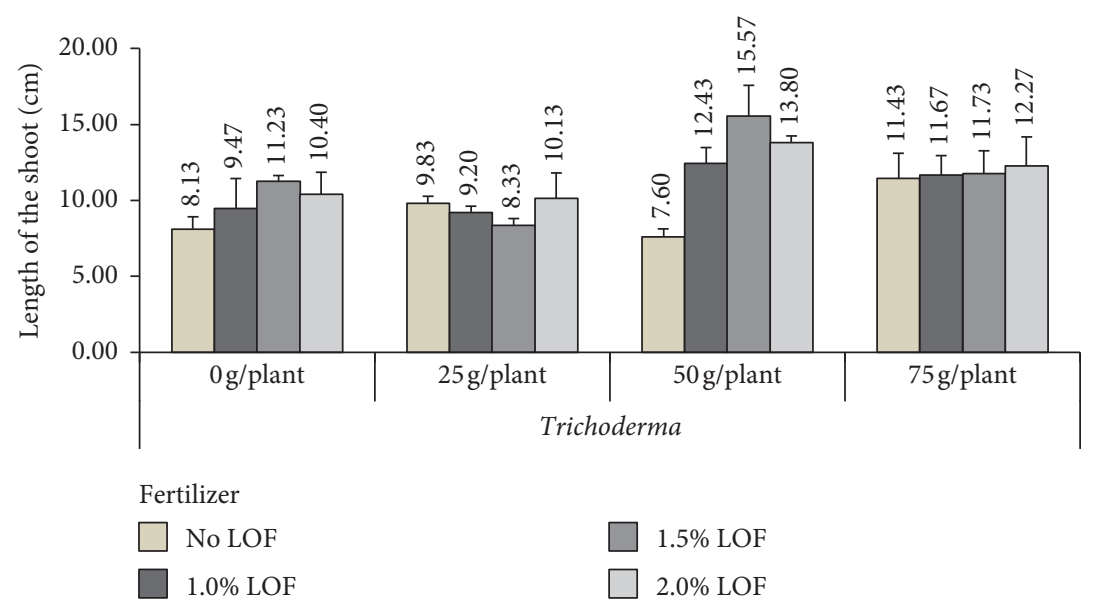

(b)

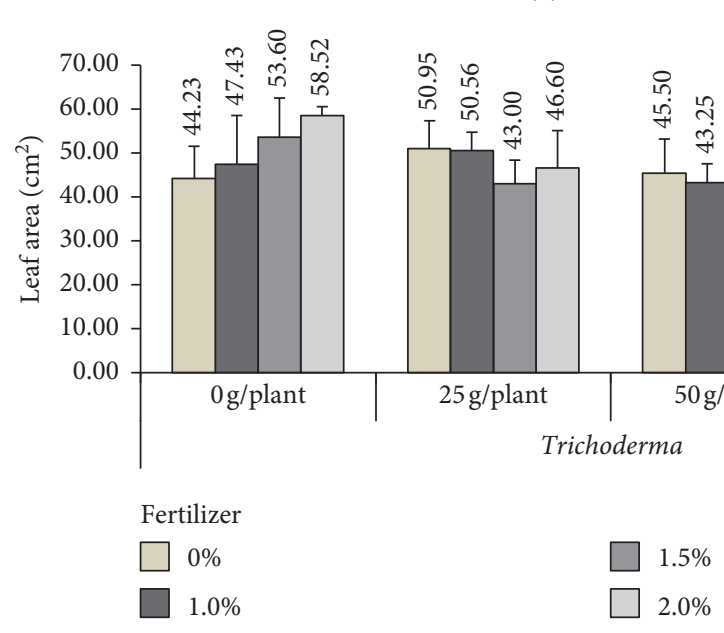

(c)

Figure 6: Effect of the combination treatment of Trichoderma and foliar fertilizer application on emergence time of the shoot (a), length of the shoot (b), and leaf area (c) of black pepper seedlings (after 8 weeks of planting). Vertical bars represent SE.

nutrients through the leaves is considered the right way to absorb nutrients.

The effect of the combination of Trichoderma and foliar fertilizer on the vegetative growth of black pepper seedlings can be seen in Figure 6. The combined application of Trichoderma and foliar fertilizer to pepper seedlings had a positive effect on shoot length, leaf numbers, and shoot emergence. Application of $50 \mathrm{~g} /$ plant of Trichoderma and $1.5 \%$ of foliar fertilizer resulted in $26 \%$ longer shoot length and $54 \%$ more leaves and accelerated the emergence time of shoots 10 days earlier compared to without Trichoderma and foliar fertilizer. Trichoderma $50 \mathrm{~g} /$ plant combined with foliar fertilizer at various concentrations is shown in Figure 7. This result was similar to studies reported by other researchers who found that foliar feeding of black pepper can only increase plant growth and production when used in combination with Trichoderma [42, 43]. Various mechanisms have been proposed to explain growth promotion including the control of minor pathogens, enhanced nutrient uptake, increased carbohydrate metabolism and photosynthesis, and

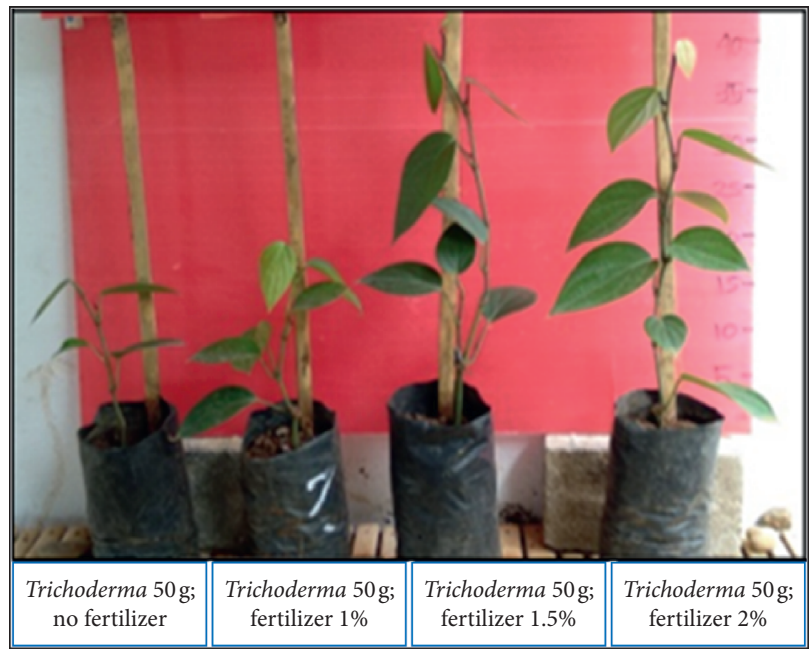

Figure 7: The length of the shoot of black pepper seedlings (after 8 weeks of planting) in combination with Trichoderma $50 \mathrm{~g} /$ plant at various concentrations of the foliar fertilizer. 
phytohormone synthesis $[23,33,44]$. There is strong evidence for the role for microbe-produced indole acetic acid (IAA), although it is most likely that Trichoderma stimulates growth by influencing the balance of hormones such as IAA, gibberellic acid, and ethylene $[45,46]$. Furthermore, Trichoderma species promote nutrient uptake by secreting organic acids to dissolve minerals and activate nutrients in the soil, leading to the circulation and utilization of nutrients in the soil [33]. At the same time, due to the strong colonization ability of Trichoderma species, they expand the contact area between the rhizosphere and soil and increase the secretion of extracellular enzymes such as sucrase, urease, and phosphatase, as well as organic acids in the rhizosphere, to improve nutrient cycling and enzyme activity in the soil [47]. Trichoderma inoculation increased the effective nutrient content and the soil enzyme activity to repair soil and promote plant growth [33]. The use of Trichoderma-based biological products will have an important role in agricultural production in the future, in light of changing worldwide perspectives by consumers and governing bodies.

\section{Conclusions}

It was found that the application of Trichoderma can only increase plant growth when used in combination with foliar fertilizer application. The sole application of Trichoderma or foliar fertilizer led to inferior vegetative growth compared to what was obtained by their combined application. Nursery trial showed that the integrated Trichoderma and foliar fertilizer are the best options for the proper nutrient management of pepper seedlings. The application of both Trichoderma and foliar fertilizer influenced the growth rate of the length of the shoot, the number of leaves, and the emergence time of the shoot of black pepper seedlings under nursery conditions. There was a positive effect of the pepper seedling for the application of $50 \mathrm{~g} /$ plant of Trichoderma and $1.5 \%$ of foliar fertilizer which resulted in $26 \%$ longer shoot length and 54\% more leaves and accelerated the emergence time of shoots 10 days earlier compared to without Trichoderma and the foliar fertilizer.

\section{Data Availability}

All data generated or analyzed during this study are included within this article.

\section{Conflicts of Interest}

The authors declare no conflicts of interest.

\section{Authors' Contributions}

Netty Syam designed the field experiment, supervised the project, and wrote the manuscript. Akbar Nurdin assisted in the field data collection and conducted data analysis. Hidrawati helped in the preparation of the manuscript. St. Sabahannur helped in manuscript review.

\section{Acknowledgments}

The authors would like to thank the Ministry of Research Technology and Higher Education of Indonesia (Grant no. 0349.a/B.07/UMI/II/2018) for funding this research.

\section{References}

[1] A. Mani, B. Chandra, and K. Viswavidyalaya, "Agriculture \& food: e-Newsletter," 2019, http://www.agrifoodmagazine.co. in/.

[2] J. G. Lee, Y. Chae, Y. Shin, and Y. J. Kim, "Chemical composition and antioxidant capacity of black pepper pericarp," Applied Biological Chemistry, vol. 63, no. 1, pp. 1-9, 2020.

[3] F. Zargar Shooshtari, M. K. Souri, M. R. Hasandokht, and S. Kalate Jari, "Glycine mitigates fertilizer requirements of agricultural crops: case study with cucumber as a high fertilizer demanding crop," Chemical and Biological Technologies in Agriculture, vol. 7, no. 1, pp. 1-10, 2020.

[4] A. Estaji, M. K. Souri, and R. Omidbaigi, "Evaluation of nitrogen and flower pruning effects on growth, seed yield and active substances of milk thistle," Journal of Essential Oil Bearing Plants, vol. 19, no. 3, pp. 678-685, 2016.

[5] Y. C. Ann, "Efficacy of organic products as black pepper foliar fertilizer," International Journal of Environment, Agriculture and Biotechnology, vol. 1, no. 3, pp. 586-592, 2016.

[6] Directorate General of Estate Crops, Tree Crop Estate of Indonesia 2018 - 2020 Pepper, Directorate General of Estate Crops, Jakarta, Indonesia, 2020.

[7] D. Wahyuno, D. Manohara, and O. Octivia Trisilawati, "Pretreatment effect of black pepper seedlings with Pseudomonas, trichoderma and mycorrhiza on foot rot disease incidence," Buletin Penelitian Tanaman Rempah Dan Obat, vol. 27, no. 1, p. 55, 2016.

[8] M. Naiji and M. K. Souri, "Nutritional value and mineral concentrations of sweet basil under organic compared to chemical fertilization," Acta Scientiarum Polonorum Hortorum Cultus, vol. 17, no. 2, pp. 167-175, 2018.

[9] S. Dehnavard, M. K. Souri, and S. Mardanlu, "Tomato growth responses to foliar application of ammonium sulfate in hydroponic culturetle," Journal of Plant Nutrition, vol. 40, no. 3 , pp. 315-323, 2017.

[10] S. L. Woo, M. Ruocco, F. Vinale et al., "Trichoderma-based products and their widespread use in agriculture," The Open Mycology Journal, vol. 8, no. 1, pp. 71-126, 2014.

[11] M. Hatamian, A. R. Nejad, M. Kafi, M. K. Souri, and K. Shahbazi, "Nitrate improves hackberry seedling growth under cadmium application,", 2020.

[12] M. Aslani and M. K. Souri, "Growth and quality of green bean (Phaseolus vulgaris L.) under foliar application of organicchelate fertilizers," Open Agriculture, vol. 3, no. 1, pp. 146-154, 2018.

[13] G. Megir and ADP, Pepper Production Technology in Malaysia, L. K. F. Liang, Ed., Malaysian Pepper Board, Sarawak, Malaysia, 2011.

[14] M. K. Souri, M. Hatamian, and T. Tesfamariam, "Plant growth stage influences heavy metal accumulation in leafy vegetables of garden cress and sweet basil," Chem Biol Technol Agric [Internet], vol. 6, no. 1, pp. 1-7, 2019.

[15] A. Najarian and M. K. Souri, "Influence of sugar cane compost as potting media on vegetative growth, and some biochemical parameters of Pelargonium $\times$ hortorum," Journal of Plant Nutrition, vol. 43, no. 17, pp. 2680-2684, 2020. 
[16] M. Kazem Souri and M. Hatamian, "Aminochelates in plant nutrition: a review," Journal of Plant Nutrition, vol. 42, no. 1, pp. 67-78, 2019.

[17] M. K. Souri and F. Y. Sooraki, "Benefits of organic fertilizers spray on growth quality of chili pepper seedlings under cool temperature," Journal of Plant Nutrition, vol. 42, no. 6, pp. 650-656, 2019.

[18] M. K. Souri, M. Naiji, and M. Aslani, "Effect of Fe-Glycine aminochelate on pod quality and iron concentrations of bean (phaseolus vulgarisL.) under lime soil conditions," Communications in Soil Science and Plant Analysis, vol. 49, no. 2, pp. 215-224, 2018.

[19] M. k. Souri, F. Y. Sooraki, and M. Moghadamyar, "Growth and quality of cucumber, tomato, and green bean under foliar and soil applications of an aminochelate fertilizer," Horticulture, Environment, and Biotechnology, vol. 58, no. 6, pp. 530-536, 2017.

[20] I. E. Summary and A. Identity, "Trichoderma harzianum Rifai Strain T-39," Technical Document, vol. 39, Article ID 119200, 1999.

[21] L. Lehar, "The experiment of the use of organic fertilizer and a biology agent (Trichoderma sp) towards the growth of potato (Solanum tuberosum L) (Pengujian pupuk organik agen hayati (Trichoderma $\mathrm{sp}$ ) terhadap pertumbuhan kentang (Solanum tuberosum L)), Jurnal Penelitian Pertanian Terapan, vol. 12, no. 2, pp. 115-124, 2012.

[22] N. A. Zin and N. A. Badaluddin, "Biological functions of Trichoderma spp. for agriculture applications," Annals of Agricultural Sciences, vol. 65, no. 2, pp. 168-178, 2020.

[23] G. E. Harman, "Trichoderma-not just for biocontrol anymore," Phytoparasitica, vol. 39, no. 2, pp. 103-108, 2011.

[24] U. Bal and S. Altintas, "Effects of trichoderma harzianum on lettuce in protected cultivation," Journal of Central European Agriculture, vol. 9, no. 1, pp. 63-70, 2008.

[25] Y. Elad, I. Chet, and Y. Henis, "Biological control ofRhizoctonia solani in strawberry fields byTrichoderma harzianum," Plant and Soil, vol. 60, no. 2, pp. 245-254, 1981.

[26] M. M. Tahat, K. M. Alananbeh, Y. A. Othman, and D. I. Leskovar, "Soil health and sustainable agriculture," Sustain, vol. 12, no. 12, pp. 1-26, 2020.

[27] D. Tilman, K. G. Cassman, P. A. Matson, R. Naylor, and S. Polasky, "Agricultural sustainability and intensive production practices," Nature, vol. 418, no. 6898, pp. 671-677, 2002.

[28] Y. A. Noroozlo, M. K. Souri, and M. Delshad, "Stimulation effects of foliar applied Glycine and glutamine amino acids on lettuce growth," Open Agriculture, vol. 4, no. 1, pp. 164-172, 2019.

[29] M. K. Souri and S. Dehnavard, "Tomato plant growth, leaf nutrient concentrations and fruit quality under nitrogen foliar applications," Advances in Horticultural Science, vol. 32, no. 1, pp. 41-47, 2018.

[30] N. Syam, A. Boceng, N. Jufri, and Suharman, "Effect of tricoderma and organic fertilizers on vegetatif growth of black Pepper (Piper nigrum L.) under field condition," IOP Conference Series: Earth and Environmental Science, vol. 260, no. 1, 2019.

[31] M. K. Souri and M. Aslani, "Beneficial effects of foliar application of organic chelate fertilizers on French bean production under field conditions in a calcareous soil," Advances in Horticultural Science, vol. 32, no. 2, pp. 265-272, 2018.

[32] A. Stewart and R. Hill, "Applications of trichoderma in plant growth promotion," in Biotechnology and Biology of Trichoderma, Elsevier, Amsterdam, The Netherlands, 2014.
[33] S. Halifu, X. Deng, X. Song, and R. Song, "Effects of two Trichoderma strains on plant growth, rhizosphere soil nutrients, and fungal community of Pinus sylvestris var. mongolica annual seedlings," Forests, vol. 10, no. 9, pp. 1-17, 2019.

[34] F. Doni, A. Isahak, C. R. Che Mohd Zain, and W. M. Wan Yusoff, "Physiological and growth response of rice plants (Oryza sativa L.) to Trichoderma spp. inoculants," $A M B$ Express, vol. 4, no. 1, pp. 45-47, 2014.

[35] P. K. Sajeesh, A Triple Combination for the Management of Late Blight Disease of Potato (Solanum tuberosum L.), Pant University, Pantnagar, Uttarakhand, India, 2015.

[36] M. K. Souri, "Aminochelate fertilizers: the new approach to the old problem; a review," Open Agriculture, vol. 1, no. 1, pp. 118-123, 2016.

[37] F. Vinale, K. Sivasithamparam, E. L. Ghisalberti et al., "A novel role for Trichoderma secondary metabolites in the interactions with plants," Physiological and Molecular Plant Pathology, vol. 72, no. 1-3, pp. 80-86, 2008.

[38] M. Ahmadi and M. Souri, "Growth and mineral elements of coriander (Corianderum sativum L.) plants under mild salinity with different salts," Acta Physiologiae Plantarum, vol. 40, pp. 94-99, 2018.

[39] M. K. Souri and S. Dehnavard, "Characterization of tomato growth and fruit quality under foliar ammonium sprays," Open Agriculture, vol. 2, no. 1, pp. 531-536, 2017.

[40] A. R. Nejad, M. Hatamian, M. Kafi, M. K. Souri, and K. Shahbazi, "Interaction of lead and nitrate on growth characteristics of ornamental judas tree (Cercis siliquastrum L.)," Open Agriculture, vol. 3, no. 1, pp. 670-677, 2018.

[41] M. K. Souri and M. Bakhtiarizade, "Biostimulation effects of rosemary essential oil on growth and nutrient uptake of tomato seedlings," Scientia Horticulturae, vol. 234, pp. 472-476, 2018.

[42] Y. C. Ann, "Physiological response and yield of pepper vines (piper nigrum L." Organic Pepper Foliar Fertilization, vol. 3, no. 6, pp. 102-109, 2019.

[43] N. Taha, S. Kamel, T. Elsakhawy, Y. Bayoumi, A. E.-D. Omara, and H. El-Ramady, "Sustainable approaches of trichoderma under changing environments for vegetable production," Environ Biodivers Soil Secur, vol. 4, no. 5, 2020.

[44] P. S. Gorai, S. Barman, S. K. Gond, and N. C. Mandal, "Chapter-28 Trichoderma," Beneficial Microbes in AgroEcology, pp. 571-591, 2020.

[45] A. Alfiky and L. Weisskopf, "Deciphering trichodermaplant-pathogen interactions for better development of biocontrol applications," Journal of Fungi, vol. 7, no. 1, pp. 1-18, 2021.

[46] J. Jaroszuk-ściseł, R. Tyśkiewicz, A. Nowak et al., "Phytohormones (Auxin, gibberellin) and ACC deaminase in vitro synthesized by the mycoparasitic trichoderma DEMTKZ3A0 strain and changes in the level of auxin and plant resistance markers in wheat seedlings inoculated with this strain conidia," International Journal of Molecular Sciences, vol. 20, no. 19, pp. 1-35, 2019.

[47] R. X. Li, F. Cai, G. Pang, Q. R. Shen, R. Li, and W. Chen, "Solubilisation of phosphate and micronutrients by Trichoderma Harzianum and its relationship with the promotion of tomato plant growth," PLoS One, vol. 10, no. 6, pp. 1-16, 2015. 